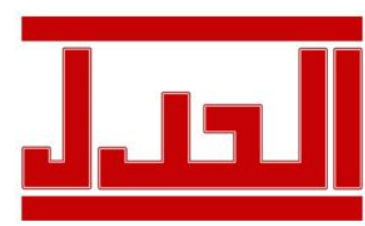

ISSN: $1979-4940$

E-ISSN: 2477-0124
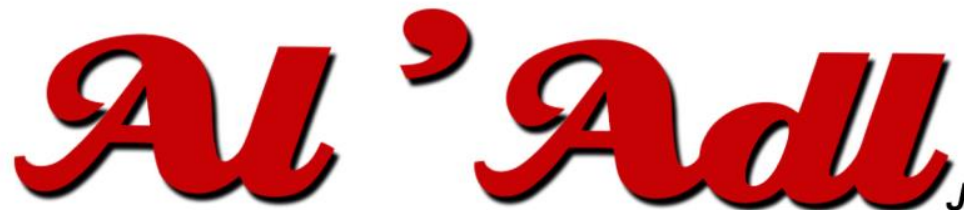

Jurnal Hukum

Editorial Office: Faculty of Law, Islamic University Of Kalimantan,

Jalan Adhyaksa No. 2 Kayutangi Banjarmasin, Kalimantan Selatan, Indonesia (70123)

Email:al_adl@uniska-bjm.ac.id

Web: http://ojs.uniska-bjm.ac.id

\title{
Efektivitas Sanksi “Pidana Bersyarat" (Analisis Terhadap Putusan Pidana Pemilu Serentak Tahun 2019 Di Provinsi Kalimantan Selatan)
}

\author{
${ }^{[1]}$ Muhammad Syahrial Fitri, ${ }^{[2]}$ Hanafi Ramsi* \\ Universitas Islam Kalimantan Muhammad Arsyad Al Banjari
}

Jl. Adhyaksa No. 2, Kayutangi, Kecamatan Banjarmasin Utara, Kota Banjarmasin;

Kalimantan Selatan 70123.

Email: $\underline{\text { iyal_888@yahoo.co.id, }{ }^{1} \text { hanafiramsi@gmail.com }}{ }^{2}$

*corresponding author

$\begin{array}{ll}\text { Submitted } & : \text { 10 November 2021 } \\ \text { Revised } & : \text { 27 Desember 2021 } \\ \text { Accepted } & : \text { 5 Januari 2022 } \\ \text { Published } & : \text { 18 Januari 2022 }\end{array}$

Jurnal Al Adl by Universitas Islam Kalimantan Muhammad Arsyad albanjari is licensed under a Creative Commons Attribution 4.0 International License. (CC-BY)

\begin{abstract}
This research will discuss, first, the effectiveness of conditional criminal sanctions in the context of the enforcement of democracy in South Kalimantan Province, second, the legal consideration of the judges who adjudicate electoral crimes at the Simultaneous General Election in South Kalimantan Province in 2019. This research applied a normative juridical research method. This normative legal research was carried out descriptivey and qualitatively - i.e. the legal materials were collected or sorted in order for the contents to be further studied and analyzed, so that the level of synchronization, the submission of new normative ideas and the feasibility of norms can be determined. The results revealed that first, the Election Criminal Verdict that occurred in Banjarbaru City, Banjarmasin City and Banjar Regency - all of which are conditional criminals, in the judicial process of election crimes, the judges judged in consideration of the verdict that condemnation (straafinaad), including the prosecution of cases of electoral criminal offenses was not a form of revenge, therefore, the consideration which the verdict handed down was more a corrective step and coached the perpetrator, second, in consideration of the verdict, there was still a difference or disparity of verdicts and the number of probationary criminal verdicts (light) showed different perspectives (paradigm) by the judges in looking at electoral criminal cases.
\end{abstract}

Keywords: Conditional Criminal Sanctions; Simultaneous elections; South Kalimantan.

\section{Abstrak}

Penelitian ini akan membahas tentang, pertama, efektifitas sanksi pidana bersyarat dalam konteks penegakan demokrasi di Provinsi Kalimantan Selatan, kedua, pertimbangan hukum majelis hakim yang mengadili perkara tindak pidana pemilu pada Pemilihan Umum Serentak Tahun 2019 di Provinsi Kalimantan Selatan. Penelitian ini menggunakan metode penelitian yuridis normatif. Penelitian hukum normatif ini dilakukan secara deskriptif kualitatif yaitu bahan-bahan hukum tersebut dikumpulkan atau materi, dipilah-pilah untuk selanjutnya dipelajari dan dianalisis muatannya, sehingga dapat diketahui taraf sinkronisasinya, pengajuan gagasan-gagasan normatif baru dan kelayakan norma. Hasil penelitian ini menunjukkan bahwa pertama, Putusan Pidana Pemilu yang 
terjadi di Kota Banjarbaru, Kota Banjarmasin dan Kabupaten Banjar, yang kesemuanya adalah pidana bersyarat dalam proses peradilan tindak pidana pemilu para hakim menilai dalam pertimbangan putusan bahwa pemidanaan (straafinaad), termasuk pemidanaan perkara pelanggaran tindak pidana pemilu bukan merupakan ajang balas dendam, sehingga dalam pertimbangan putusan yang dijatuhkan lebih merupakan langkah korektif dan pembinaan terhadap pelaku, kedua, dalam pertimbangan putusan masih adanya perbedaan atau disparitas putusan dan banyaknya vonis pidana percobaan (ringan) menunjukkan adanya perbedaan perspektif (paradigma) oleh para hakim dalam memandang kasus tindak pidana pemilu.

Kata Kunci: Sanksi Pidana Bersyarat; Pemilu Serentak; Kalimantan Selatan.

\section{PENDAHULUAN}

Penyelenggaraan pemilu di Indonesia telah dilakukan sejak tahun 1955. Pemilihan umum yang diadakan pada September dan Desember 1955 sangat menarik sebagai suatu eksperimen demokrasi. Pemilihan umum 1955 ini adalah yang pertama kali dilaksanakan secara nasional di Indonesia. ${ }^{1}$ Sejarah dan pengalaman pelaksanaan pemilu atau sistem perwakilan telah terlaksana sejak zaman koloni dan pemilu di daerah (pilkada) seperti Minahasa (Sulawesi Selatan) dan Yogyakarta. Sejak era Soeharto atau lebih identik dengan rezim "Orde Baru," pemilu telah terlaksana secara berturut-turut pada tahun, 1971, 1977, 1982, 1987, 1992 dan 1997.

Pemilu berikutnya seharusnya dilaksanakan pada tahun 2002, namun karena kondisi politik, sosial dan krisis ekonomi yang berlarut saat itu maka pada tahun 1998 yang akhirnya meruntuhkan dominasi rezim Soeharto, maka pemilu dilaksanakan tahun 1999 dan Indonesia menjadi negara yang berhasil mengadakan pemilu paling demokratis sejak 30 tahun. Pemilu terakhir dilaksanakan pada tahun 2014 yang menghasilkan anggota Dewan Perwakilan Rakyat Republik Indonesia dan Dewan Perwakilan Rakyat Daerah Provinsi dan Dewan Perwakilan Rakyat Daerah Kabupaten/Kota seluruh Indonesia serta menghasilkan pasangan Presiden dan Wakil Presiden. Pada April 2019 yang lalu telah dilakukan pemungutan suara serentak di seluruh Indonesia, untuk memilih sekaligus Presiden dan Wakil Presiden, anggota Dewan Perwakilan Rakyat Republik Indonesia (DPR RI), Dewan Perwakilan Daerah (DPD), Dewan Perwakilan Rakyat Daerah (DPRD) Provinsi dan Dewan Perwakilan Rakyat Daerah (DPRD) Kabupaten/Kota.

Berbeda dengan pemilu-pemilu sebelumnya, pemilu serentak yang dilaksanakan pada Tahun 2019 langsung memilih Presiden dan Wakil Presiden Republik Indonesia, anggota Dewan Perwakilan Rakyat, anggota Dewan Perwakilan Daerah dan anggota Dewan Perwakilan Rakyat Daerah. Seluruh jabatan penting itu akan dihasilkan melalui suatu proses

1 Topo Santoso, Ida Budhiati, (2019), Pemilu Di Indonesia Kelembagaan, Pelaksanaan, dan Pengawasan, Jakarta: Sinar Grafika, hlm. 15. 
demokrasi yang sangat penting yaitu pemilihan umum. Sebelumnya, kita telah melalui pemilihan umum demokratis 2014, 2009, 2004 dan 1999 dengan selamat dan dianggap cukup demokratis. Meski demikian, bukan berarti dalam proses itu tidak ada masalah yang terjadi. Dalam proses pemilu terdapat cukup banyak persoalan pelanggaran administratif, tindak pidana pemilu, sengketa pemilu, pelanggaran kode etik penyelenggara pemilu, dan perselisihan hasil pemilihan umum (PHPU) di Mahkamah Konstitusi RI.

Tindak pidana pemilu tidak hanya diatur baru-baru ini saja, melainkan dalam setiap pemilu di Indonesia sejak tahun 1955, pemilu-pemilu Orde Baru, hingga pemilu-pemilu era reformasi juga sudah diatur. Bahkan dalam Kitab Undang-Undang Hukum Pidana (KUHP) terdapat lima tindak pidana pemilu yang diatur di Pasal 148 sampai Pasal 152. Pasal-pasal itu mengancam pidana perbuatan penyuapan, perbuatan tipu muslihat, mengaku sebagai orang lain, dan menggagalkan pemungutan suara. Tindak pidana pemilu tidak hanya ditemui dalam undang-undang pemilu di negara kita, di negara lain pun juga ada tindak pidana pemilu yang dikenal dengan sebutan election offences, election fraud, corrupt practices, dan sebagainya. Dengan demikian, setiap negara yang menyelenggarakan pemilu menyadari bahwa untuk melindungi proses pemilu agar berlangsung secara free and fair, maka salah satu yang diperlukan adalah adanya aturan pidana yang mengancam sejumlah perbuatan yang membahayakan proses pemilu. Dengan demikian, hukum pidana memiliki peranan juga dalam pelaksanaan pemilu, dalam proses demokrasi di masing-masing negara.

Dalam Undang-Undang Nomor 7 Tahun 2017 tentang Pemilihan Umum tidak ada definisi Tindak Pidana Pemilu. Dalam Undang-Undang Nomor 8 Tahun 2012 tentang Pemilihan Umum Anggota DPR, DPD, DPRD, Tindak Pidana Pemilu didefinisikan sebagai pelanggaran terhadap ketentuan pidana Pemilu yang diatur dalam Undang-Undang yang penyelesaiannya dilaksanakan melalui pengadilan dalam lingkungan peradilan umum. Landasan hukum Pemilihan Umum Serentak Tahun 2019 adalah Undang-Undang Nomor 7 Tahun 2017 tentang Pemilihan Umum, terdapat 77 tindak pidana pemilihan umum yang diatur di 66 Pasal ketentuan pidana. Jumlah ini meningkat dibanding undang-undang Pemilu sebelumnya, di Undang-Undang Nomor 8 Tahun 2012 terdapat 56 tindak pidana Pemilu yang diatur di 48 Pasal. Sanksi pidana yang diancamkan bagi pelaku Tindak Pidana Pemilihan Umum ada beberapa macam yakni pidana penjara, pidana kurungan, dan pidana denda. 
Sanksi pidana penjara dan denda diancamkan secara kumulatif. Tidak dinyatakan secara tegas tindak pidana mana yang jenisnya kejahatan dan mana yang pelanggaran. ${ }^{2}$

Proses penegakan hukum pemilu dalam penangannya merupakan mahkota untuk menggaransi terselenggaranya pemilu yang adil dan demokratis. Maka penegakan hukum pemilu ditujukan agar aktor pemilu dapat mematuhi aneka peraturan perundang-undangan yang mengatur tentang Pemilu dan hak politik dan pilih masyarakat dapat diwujudkan. Oleh karena itu dalam penegakan hukum pemilu yang hendak diwujudkan adalah keadilan Pemilu yang mengutamakan pada konsep keadilan substantif dalam proses penyelenggaraan antara aktor pemilu, yakni pemilih, peserta pemilu dan penyelenggara Pemilu. ${ }^{3}$

Bentuk-bentuk Tindak Pidana Pemilihan Umum sebagaimana yang dimaksud Pasal 1 Ayat (1) Undang-Undang Nomor 7 tahun 2017 tentang Pemilihan Umum yang berasas LUBER di dalam Negara Kesatuan Republik Indonesia berdasarkan Pancasila UndangUndang Dasar Negara Republik Indonesia Tahun 1945”. Dan pemilihan umum dilaksanakan satu kali dalam masanya 5 (lima) tahun, ini sesuai dengan Pasal 22E Ayat (1) UndangUndang Dasar Negara Republik Indonesia Tahun 1945 berbunyi, "Pemilihan umum dilaksanakan secara langsung, umum, bebas, rahasia, jujur, dan adil setiap lima tahun sekali”. Sudah tentu bahwa tindak pidana pemilihan umum itu hanya terjadi dalam kurung waktu tersebut, akan tetapi pelanggaran terhadap tindak pidana pemilihan umum yang terjadi 5 (lima) tahun sekali ini perlu di tindak terhadap pelanggarannya. Meskipun dilakukan 5 (lima) tahun sekali pemilu itu adalah hal yang hakiki atau penting dalam suatu negara yang demokrasi dan Pemilu itu tidak boleh cacat dan ternoda dalam pelaksanaannya.

Perbuatan tindak pidana Pemilu sebelum terbitnya Undang-Undang Pemilu sudah diatur dalam Kitab Undang-Undang Hukum Pidana (KUHP) yaitu Pasal 148, Pasal 149 Ayat (1) dan Ayat (2), Pasal 150, Pasal 151 dan Pasal 152 Kitab Undang-Undang Hukum Pidana (KUHP). Disamping TPPU yang diatur dalam KUHP juga diatur lebih rinci dan tegas terhadap tindak pidana pemilu dalam Undang-Undang Republik Indonesia Nomor 1 Tahun 2017 tentang Pemilihan Umum. ${ }^{4}$

2 Topo Santoso, (2019), "Tindak Pidana Pemilu Di Indonesia: Tinjauan Beberapa Kasus", Makalah Pidana Pemilu, Fakultas Hukum: Universitas Indonesia, hlm. 2-3 yang disampaikan pada Rapat Koordinasi Putusan Pidana Pemilu, Banjarmasin, 28 Juni 2019.

${ }^{3}$ Agus Riwanto, (2020), "Model Pengintegrasian Penegakan Hukum Pilkada Serentak Guna Mewujudkan Keadilan Substantif (Evaluasi Penegakan Hukum Pilkada Serentak 2015-2020)”, Jurnal Adhyasta Pemilu, Volume 7 Nomor 1 Tahun 2020, hlm. 63.

4 Dudung Mulyadi, (2019), “Analisis Penerapan Bentuk-Bentuk Tindak Pidana Pemilu”, Jurnal Ilmiah Galuh Yustisi, Volume 7 Nomor 1, hlm. 24. 
Berkenaan penanganan terhadap dugaan tindak pidana pemilihan umum dilakukan di dalam wadah khusus yang dinamakan Sentra Penegakan Hukum Terpadu (Sentra Gakkumdu), pada pidana Pemilihan Umum Serentak Tahun $2019^{5}$ di Provinsi Kalimantan Selatan terdapat 4 kasus pidana pemilihan umum yang telah incrach di Pengadilan, yakni di Sentra Gakkumdu Bawaslu Provinsi Kalimantan Selatan, Sentra Gakkumdu Bawaslu Kota Banjarmasin, Sentra Gakkumdu Bawaslu Kota Banjarbaru, dan Sentra Gakkumdu Bawaslu Kabupaten Banjar. Dari 4 kasus di atas, berkenaan dengan sanksi pidana pemilu sebagaimana yang telah dijelaskan di atas bahwasanya ada beberapa macam yakni pidana penjara, pidana kurungan, dan pidana denda. Di dalam ketentuan pidana pemilu di dalam Undang-Undang Nomor 7 Tahun 2017 tentang Pemilihan Umum tidak dikenal dengan saksi hukum pidana pemilu dengan "pidana bersyarat" sebagaimana KUHP mengatur atau yang lebih familiar dikenal dengan istilah "pidana percobaan".

Akan tetapi dalam prakteknya dari 4 kasus di atas, terdapat 3 kasus pidana pemilu yang ditangani oleh Bawaslu Kota Banjarmasin, Banjarbaru dan Bawaslu Kabupaten Banjar yang dalam salah satu diktum putusannya majelis hakim menyatakan bahwa “.....pidana penjara tidak perlu dijalani, kecuali jika kemudian hari ada putusan hakim yang menentukan lain, disebabkan terpidana melakukan suatu tindak pidana sebelum berakhirnya masa percobaan.....", 1 kasus yang ditangani Bawaslu Provinsi Kalimantan Selatan, sanksi hukuman pidananya yakni pidana penjara selama 2 bulan dan pidana denda. Jika kita merujuk ketentuan Pasal 14a Kitab Undang-Undang Hukum Pidana (KUHP) menurut Prof. Dr. Wijono Prodjodikoro, S.H dalam bukunya “Asas-Asas Hukum Pidana di Indonesia”, Pasal ini bisa dikatakan sebagai saksi pidana bersyarat.

Menariknya putusan pidana pemilu di atas, Undang-Undang Nomor 7 Tahun 2017 tentang Pemilihan Umum tidak mengenal saksi pidana bersyarat, sehingga membuat peneliti sangat tertarik untuk melakukan penelitian yang akan dituangkan dalam sebuah kajian yang bersifat ilmiah yang menitikberatkan terhadap pertimbangan-pertimbangan majelis hakim dan efektifitas sanksi dalam ketiga putusan perkara tersebut dalam konteks penegakkan demokrasi terkhusus di Provinsi Kalimantan Selatan kedepan.

\section{RUMUSAN MASALAH}

\footnotetext{
${ }^{5}$ Undang-Undang Republik Indonesia Nomor 7 Tahun 2017 tentang Pemilihan Umum, Peraturan Badan Pengawas Pemilu Nomor 21 Tahun 2018 tentang Pengawasan Penyelenggaraan Pemilihan Umum, Peraturan Badan Pengawas Pemilu Nomor 7 Tahun 2018 tentang Penanganan Temuan dan Laporan, Peraturan Badan Pengawas Pemilihan Umum Republik Indonesia Nomor 31 Tahun 2018 tentang Sentra Penegakan Hukum Terpadu.
} 
Adapun yang menjadi rumusan masalah dalam penelitian ini adalah:

1. Bagaimana efektifitas sanksi pidana bersyarat dalam konteks penegakan demokrasi di Provinsi Kalimantan Selatan?

2. Bagaimana pertimbangan-pertimbangan hukum majelis hakim yang mengadili perkara tindak pidana pemilu pada Pemilihan Umum Serentak Tahun 2019 di Provinsi Kalimantan Selatan?

\section{METODE PENELITIAN}

Penelitian ini dilakukan dengan metode pendekatan Yuridis Normatif, ${ }^{6}$ yaitu suatu pendekatan dengan menelaah peraturan perundang-undangan dan bahan pustaka lainnya yang berkaitan dengan sanksi pidana bersyarat dalam dalam pemilu. Pengkajian peraturan perundang-undangan dan bahan pustaka tersebut sekaligus digunakan sebagai bahan untuk melakukan pembahasan dan menemukan pemecahan masalah. Dalam penelitian hukum ini dilakukan beberapa pendekatan guna untuk mendapatkan informasi dari berbagai aspek mengenai isu yang akan dipecahkan dalam penelitian ini. Beberapa pendekatan tersebut:

a. Pendekatan Undang-Undang (Statute Approach), yaitu pendekatan yang dilakukan dengan cara menelaah semua Undang-Undang dan regulasi yang berkaitan dengan isu hukum yang sedang ditangani. ${ }^{7}$

b. Pendekatan Kasus (Case Approach), yaitu pendekatan yang dilakukan dengan menggunakan ratio decidendi, yaitu alasan-alasan hukum yang digunakan oleh hakim untuk sampai kepada putusannya. ${ }^{8}$

Tipologi penelitian ini adalah preskriptif, yaitu dengan menggambarkan bagaimana seharusnya kewenangan regulasi dibentuk dan bagaimana seharusnya saksi pidana pemilu. Bahan hukum atau sumber hukum yang digunakan untuk penelitian hukum ini adalah bahan hukum primer, yaitu putusan-putusan pengadilan yang berkaitan dengan isu hukum yang dihadapi, bahan hukum sekunder yaitu bahan-bahan yang memberikan informasi atau hal-hal yang berkaitan isi sumber hukum primer serta implementasinya, bahan hukum tersier yaitu bahan-bahan hukum yang memberikan penjelasan terhadap bahan-bahan hukum primer dan

\footnotetext{
${ }^{6}$ Penelitian hukum normatif atau penelitian hukum kepustakaan adalah penelitian hukum yang dilakukan dengan cara meneliti bahan pustaka atau data sekunder. Penelitian hukum normatif atau kepustakaan tersebut mencakup penelitian terhadap asas-asas hukum, penelitian terhadap sistematik hukum, penelitian terhadap taraf sinkronisasi vertikal dan horizontal, perbandingan hukum, dan sejarah hukum. Dikutip dari Soerjono Soekanto dan Sri Mamudji, (2011), Penelitian Hukum Normatif Suatu Tinjauan Singkat, Cet. 13, Jakarta: Rajawali Pers, hlm. 13-14.

${ }^{7}$ Peter Mahmud Marzuki, (2014), Penelitian Hukum, Jakarta : Pranamedia Group, hlm.133.

${ }^{8}$ Ibid., hlm. 135.
} 
sekunder, yaitu kamus hukum dan berbagai literatur hukum lain yang relevan. Alat pengumpulan data menggunakan metode pengumpulan data studi kepustakaan yang dilakukan dengan menelaah putusan-putusan, literatur-literatur, majalah, surat kabar, karya ilmiah, jurnal serta perundang-undangan yang berhubungan dengan penelitian di atas, kemudian melalui metode itu dibuat analisa hukum antara regulasi dan praktik yang dilaksanakan dengan permasalahan yang ada dan metode analisis datanya menggunakan analisis deskriptif kualitatif yaitu upaya untuk memperoleh gambaran singkat suatu permasalah yang didasarkan atas peraturan perundang-undangan yang berlaku dan berhubungan dengan permasalahan yang dibahas dalam penelitian ini kemudian disusun secara logis dan sistematis.

\section{PEMBAHASAN}

Secara umum dapat dikatakan bahwa pidana bersyarat adalah suatu sistem penjatuhan pidana oleh Hakim yang pelaksanaannya digantungkan pada syarat-syarat tertentu. Artinya, pidana yang dijatuhkan oleh Hakim itu ditetapkan tidak perlu dijalankan pada terpidana selama syarat-syarat yang ditentukan tidak dilanggarnya, dan pidana dapat dijalankan apabila syarat-syarat yang ditetapkan itu tidak ditaatinya atau dilanggarnya. Tentu saja pidana bersyarat ini diberikan dengan adanya suatu maksud. Pidana bersyarat ini bertujuan untuk memberikan kesempatan kepada terpidana agar dalam waktu yang telah ditentukan memperbaiki diri untuk tidak melakukan suatu perbuatan pidana lagi.

Lembaga pidana bersyarat timbul berdasarkan suatu pemikiran yaitu bahwa tidaklah semua penjahat (terpidana) harus dimasukkan ke dalam penjara, akan tetapi khususnya terhadap pelanggaran pertama kali demi mencegah adanya pengaruh lingkungan masyarakat narapidana tersebut diberikan kesempatan untuk memperbaiki dirinya di luar penjara. ${ }^{9}$

Di Indonesia sendiri Lembaga yang mempunyai kewenangan untuk mengadili dan menjatuhkan sanksi disebut lembaga peradilan, yang didalamnya terdapat aparatur negara yang melaksanakan kewenangan untuk mengadili dan memutus suatu perkara atau masalah yang terjadi di dalam masyarakat yang kita kenal sebagai Hakim. Tugas hakim sesunguhnya adalah sebuah tugas yang mulia, sebagaimana dijelaskan oleh Roeslan Saleh, tentang sebuah “Pergulatan kemanusiaan”. Dalam pernyataan tersebut terlihat besarnya tanggung jawab seorang hakim dalam menjalankan tugasnya, dimana mereka harus menghadapi pergulatan batin serta gejolak dalam jiwanya ketika harus membuat suatu pilihan-pilihan yang tidak

9 Sapto Handoyo D.P, (2018), "Pelaksanaan Pidana Bersyarat Dalam Sistem Pemidaan Di Indonesia", Pakuan Law Review, Volume IV Nomor 1, hlm. 26. 
mudah dalam membuat suatu Putusan dalam perkara yang diadilinya, dan lebih dari itu semua seorang hakim juga harus meletekan telinganya pada pendapat dan rasa keadilan yang di harapkan oleh masyarakat.

Dengan demikian sebuah putusan hakim merupakan cermin dari sikap, moralitas, penalaran dan banyak hal lainnya yang dideskripsikan sebagai pengalaman seorang hakim dalam menjalankan tugas dan fungsinya. Hal ini menunjukan kepada kita bahwa sebenarnya putusan hakim sangat bersifat relativisme cultural sehingga tidak menutup kemungkinan pandangan setiap hakim dalam suatu perkara bisa berbeda-beda. Pada Umumnya seorang hakim akan merujuk pada pidana pokok dan pidana tambahan, seperti yang diatur dalam Pasal 10 KUHP. Dimana dalam sanksi pidana yang diatur dalam Pasal 10 KUHP tersebut, salah satunya adalah sanksi pidana penjara, dimana sanksi perampasan kemerdekaan inilah yang cukup sering di jatuhkan oleh hakim di dalam putusanya karena di anggap lebih efektif dan dapat membuat pelaku tindak pidana menjadi jera. Akan tetapi dalam penerapan sanksi pidana penjara ini sendiri memiliki dampak negatif yang cukup besar, baik bagi terpidana secara individu maupun bagi masyarakat secara sosial oleh sebab itu diperlukan suatu alternatif pemidanaan dari sanksi pidana penjara itu sendiri.

Dalam praktek peradilan Pidana, KUHP sendiri telah mengatur tentang alternatif dari sanksi pidana penjara tersebut yaitu tentang pemidanaan bersyarat, yang telah diatur dalam Pasal 14a sampai dengan Pasal 14f KUHP. Pidana bersyarat itu sendiri merupakan alternatif dari pidana perampasan kemerdekaan yang bersifat non intitusional yang dapat dijatuhkan oleh hakim kepada terpidana, yang di vonis penjara dibawah 1 tahun dan hakim berkeyakinan terhadap terdakwa tersebut dapat dilakukannya pengawasan yang cukup terhadap dipenuhinya syarat-syarat yang telah di tetapkan kepadanya.

Penjatuhan Putusan pidana bersyarat sebenarnya bertujuan untuk menghindarkan pengaruh buruk bagi terpidana dari efek negatif penjatuhan pidana penjara yang saat ini dinilai kurang efektif bagi perbaikan diri si terpidana, selain itu penjatuhan pidana bersyarat oleh hakim dapat menjadi solusi dari pemecahan masalah daya tampung Lapas di indonesia yang telah mengalami "Overload" yang disebabkan jumlah terpidana yang divonis dengan sanksi pidana penjara terus meningkat. Oleh sebab itu Penerapan pidana bersyarat itu sendiri dianggap perlu sebagai alternatif pemidanaan dari sanksi pidana penjara saat ini. ${ }^{10}$

${ }^{10}$ Firmansyah Arifin, (2015), "Penegakan Hukum Pemilu: Tinjauan Atas Putusan Pengadilan Tindak Pidana Pemilu 2014", Jurnal Hukum Prioris, Volume 4 Nomor 3, hlm. 2-3. 


\section{Efektifitas Sanksi Pidana Bersyarat Dalam Konteks Penegakan Demokrasi Di Provinsi} Kalimantan Selatan

Dalam penjelasannya Pidana bersyarat adalah pidana dengan syarat-syarat tertentu. Pidana bersyarat ini di atur dalam Pasal 14a Kitab Undang-Undang Hukum Pidana (KUHP) yang berbunyi:

1. Apabila hakim menjatuhkan pidana paling lama satu tahun atau pidana kurungan, tidak termasuk pidana kurungan pengganti maka dalam putusannya hakim dapat memerintahkan pula bahwa pidana tidak usah dijalani, kecuali jika di kemudian hari ada putusan hakim yang menentukan lain, disebabkan karena si terpidana melakukan suatu tindak pidana sebelum masa percobaan yang ditentukan dalam perintah tersebut di atas habis, atau karena si terpidana selama masa percobaan tidak memenuhi syarat khusus yang mungkin ditentukan lain dalam perintah itu.

2. Hakim juga mempunyai kewenangan seperti di atas, kecuali dalam perkara-perkara yang mengenai penghasilan dan persewaan negara apabila menjatuhkan pidana denda, tetapi harus ternyata kepadanya bahwa pidana denda atau perampasan yang mungkin diperintahkan pula akan sangat memberatkan si terpidana. Dalam menerapkan Ayat ini, kejahatan dan pelanggaran candu hanya dianggap sebagai perkara mengenai penghasilan negara, jika terhadap kejahatan dan pelanggaran itu ditentukan bahwa dalam hal dijatuhkan pidana denda, tidak diterapkan ketentuan Pasal 30 Ayat 2.

Sederhananya, penjelasan mengenai pidana penghukuman bersyarat (pidana bersyarat) yang diatur dalam Pasal 14a dan seterusnya dalam KUHP, bahwa apabila seorang dihukum penjara selama-lamanya satu tahun atau kurungan, maka hakim dapat menentukan bahwa hukuman itu tidak dijalankan. Kecuali, kemudian ditentukan lain oleh hakim, seperti apabila si terhukum dalam tenggang waktu percobaan melakukan tindak pidana lagi atau tidak memenuhi syarat tertentu, misalnya tidak membayar ganti kerugian kepada si korban dalam waktu tertentu.

Itu artinya, meskipun terdakwa dinyatakan bersalah dan dihukum dengan hukuman penjara, tidak perlu dimasukkan penjara atau lembaga pemasyarakatan asalkan selama masa percobaan dapat memperbaiki kelakuannya. Hal ini dilatarbelakangi pemikiran yang ingin memberi kesempatan pada pelaku tindak pidana untuk memperbaiki perilakunya di dalam masyarakat. Selain itu untuk menghilangkan kesan beratnya hukuman pidana dan adanya balas dendam. Hukuman semacam ini jarang sekali dijalankan karena si terhukum akan berusaha benar-benar dalam masa percobaan tidak melakukan suatu tindak pidana dan syarat 
khusus biasanya dipenuhi. Di samping itu, apabila syarat-syarat dipenuhi, baik syarat yang bersifat umum dan syarat yang bersifat khusus, ${ }^{11}$ hukuman tidak otomatis dijalankan, tetapi harus ada putusan lagi dari hakim artinya bahwa dalam masa percobaan terdakwa yang telah divonis menjalani pidana bersyarat, yang dalam masa percobaannya melakukan kembali suatu tindak pidana, putusan pidana percobaan terdahulu tidak serta merta langsung dapat dilaksanakan sebagaimana ketentuan syarat-syarat putusan sebelumnya ada kemungkinan hakim belum memerintahkan supaya hukuman dijalankan, yaitu apabila misalnya si terhukum dapat menginsafkan hakim bahwa si terhukum dapat dimaafkan dalam hal ini tidak memenuhi syarat-syarat. Akhirnya dalam praktik, pertimbangan semacam ini, mungkin sekali penghukuman bersyarat ini sama sekali tidak dirasakan sebagai hukuman (deterrence effect).

Demikian halnya dengan denda, secara filosofis dimaknai sebagai pendera. Bukan untuk mengganti kerugian, memperkaya negara atau memiskinkan pelaku. Masalahnya vonis ringan berupa percobaan tersebut banyak diberikan terhadap kasus tindak pidana pemilu yang ancaman hukumannya lebih dari 1 tahun. Misalnya, dalam kasus pidana politik uang yang ancaman hukumannya 2 - 4 tahun dan denda Rp. 24 - 48 juta, lebih banyak divonis dengan pidana percobaan. Setidaknya ada 29 kasus (56\%) dan 53 kasus politik uang yang divonis dengan pidana penjara percobaan. Sedangkan yang dipidana penjara/ditahan ada 20 kasus (37\%). Rata-rata divonis antara 1 bulan-1 tahun, dengan denda Rp. 500 ribu - 3 juta. Vonis percobaan dijatuhkan juga dalam kasus pidana pemilu mengubah hasil suara pemilu yang diancam hukuman penjara 4 tahun dan denda Rp 48 juta. Terdapat 11 kasus (26\%) dan 53 kasus yang divonis pidana percobaan. Bahkan dalam tindak pidana pemilu menggunakan dokumen/surat palsu yang diancam hukuman maksimal 6 tahun dan denda Rp 72 juta, dari 6 putusan paling tinggi hanya diganjar hukuman 6 bulan dan denda Rp 20 juta.

Banyaknya vonis ringan itu tentu belum sejalan dengan semangat pemindanaan dalam UU Pemilu, dan tidak memberikan efek jera (detterent effect). Terlebih jika pelakunya adalah para caleg dan penyelenggara, yang diharapkan bisa dipercaya dan mengikuti aturan main secara jujur (fair). Mahkamah Agung dalam Surat Edaran Nomor 1 Tahun 2000 tentang Pemidanaan Yang Setimpal Dengan Berat dan Sifat Kejahatannya, pernah meminta kepada seluruh hakim agar "menjatuhkan pidana yang sungguh-sungguh setimpal dengan beratnya dan sifatnya tindak pidana tersebut dan jangan sampai menjatuhkan pidana yang menyinggung rasa keadilan di dalam masyarakat". Namun pada kenyataannya dalam kasus tindak pidana pemilu, masih banyak yang diberi putusan yang kurang setimpal, artinya bahwa

\footnotetext{
${ }^{11}$ Lihat ketentuan Pasal 14a, Pasal 14b dan Pasal 14c, Kitab Undang-Undang Hukum Pidana.
} 
pidana percobaan masih belum efektif memberikan efek jera terhadap pelaku tindak pidana dalam penegakan hukum demokrasi di Indonesia.

Dalam konteks hukum efektifitas penanganan pelanggaran hukum melalui UndangUndang Nomor 7 Tahun 2017 mengatur keberadaan forum koordinasi dalam proses penanganan setiap pelanggaran tindak pidana pemilu, yang diberi nama Sentra Penegakan Hukum Terpadu atau disingkat Gakkumdu. ${ }^{12}$ Sentra Gakkumdu mengandung makna bahwa keberadaan dan fungsi Gakkumdu sesuai dengan kebutuhan hukum yang telah ditetapkan dalam peraturan perundang-undangan dan memberi manfaat optimal dalam penegakkan tindak pidana pemilu. Efektifitas Gakkumdu dalam rangka menegakkan keadilan Pemilu, menjamin kepastian hukum dalam penyelenggaraan pemilu serta memberi manfaat terhadap Perihal Penegakan Hukum Pemilu kelangsungan demokrasi berdasarkan hukum dalam Pemilu. Perlunya jaminan kepastian hukum bagi penyelenggara Pemilu agar terlaksana semua tahapan Pemilu sesuai dengan peraturan perundangan Pemilu. Bagi masyarakat/rakyat pemilih terjamin hak-hak hukum untuk menggunakan hak pilihnya secara langsung bebas dan rahasia. Dan bagi peserta Pemilu mendapat perlakuan secara adil dan setara dalam mengikuti Pemilihan Umum.

Secara kuantitatif laporan dugaan tindak pidana Pemilu pada Pemilu tahun 2019 sebanyak 582 perkara dan putusan pengadilan sebanyak 337 putusan. laporan dugaan tindak pidana Pemilu sebanyak 582 perkara dan yang diproses sampai pada tingkat pengadilan sebanyak 337 putusan atau sekitar lebih dari 50\% (lima puluh persen) laporan yang masuk ke Bawaslu ditindaklanjuti sampai pada tingkat pengadilan. Oleh karena itu keberadaan Gakkumdu dipandang sangat efektif dalam penanganan penindakan tindak pidana Pemilu pada penyelenggaraan Pemilihan Umum Tahun 2019.

\section{Pertimbangan-Pertimbangan Hukum Majelis Hakim Yang Mengadili Perkara Tindak} Pidana Pemilu Pada Pemilihan Umum Serentak Tahun 2019 Di Provinsi Kalimantan

\section{Selatan}

\section{Pertimbangan Putusan Nomor 568/Pid.Sus/2019/PN Bjm}

\section{a. Unsur "Pelaksana, peserta/tim kampanye"}

Bahwa Peserta Pemilu adalah partai politik untuk Pemilu anggota DPR, anggota DPRD provinsi, anggota DPRD kabupaten/kota, perseorangan untuk Pemilu anggota

${ }^{12}$ Sudi Prayitno, (2020), “Call For Paper Evaluasi Pemilu Serentak 2019 Bidang Evaluasi Aspek Hukum Pemilu, Problematika Penegakan Hukum Tindak Pidana Pemilu 2019”, Journal KPU, hlm. 11. 
OPD, dan pasangan calon yang diusulkan oleh partai politik atau gabungan partai politik untuk Pemilu Presiden dan Wakil Presiden (Pasal 1 angka 27 UU No. 7 Tahun 2017 dan Pasal 1 angka 15 PKPU No. 23 Tahun 2018);

Bahwa dalam Pasal ini disebut "Pelaksana, peserta dari atau tîm kampanye", menurut Majelis Hakim dalam perkara a quo menunjukkan tentang subyek hukum yang didakwa melakukan tindak pidana dimaksud, dalam hal ini subyek hukum adalah kedudukan terdakwa F sebagai Calon anggota Legislatif DPRD Provinsi sebagaimana dimaksud dalam Pasal 13 Ayat (1) PKPU No. 23 Tahun 2018, Pelaksana Kampanye untuk Pemilu Anggota DPRD Provinsi terdiri atas:

1. Pengurus partai politik Peserta Pemilu DPRD Provinsi;

2. Calon anggota DPRD Provinsi;

3. Juru Kampanye;

4. Orang seorang; dan

5. Organisasi Penyelenggara Kegiatan yang ditunjuk oleh Peserta Pemilu Anggota DPRD Provinsi

Bahwa dengan demikian unsur "Pelaksana, peserta dan/atau tim kampanye" telah terpenuhi ada pada diri terdakwa. Kemudian unsur "Dengan sengaja menjanjikan atau memberikan uang atau materi lainnya sebagai imbalan kepada peserta kampanye pemilu baik secara langsung maupun tidak langsung”.

Bahwa menurut penjelasan Pasal 284 dan Pasal 286 Undang-Undang Nomor 7 Tahun 2017 tentang Pemilihan Umum, yang dimaksud dengan "menjanjikan atau memberikan" adalah inisiatifnya berasal dari pelaksana dan tim Kampanye Pemilu yang menjanjikan dan memberikan untuk memengaruhi Pemilih. Selanjutnya yang dimaksud dengan "materi lainnya" tidak termasuk meliputi pemberian barang - barang yang merupakan atribut Kampanye Pemilu, antara Iain kaus, bendera, topi dan atribut lainnya serta biaya makan dan minum peserta kampanye, biaya transport peserta kampanye, biaya pengadaan bahan kampanye pada pertemuan terbatas dan/atau pertemuan tatap muka dan dialog, dan hadiah lainnya berdasarkan nilai kewajaran dan kemahalan suatu daerah yang ditetapkan dengan Peraturan KPU;

Bahwa memberikan uang atau materi lainnya adalah suatu pemberian yang telah diserahkan baik berupa uang dalam bentuk mata uang apapun atau materi lainnya selain dalam bentuk uang. Materi lainnya tersebut dapat berupa benda bergerak atau tidak bergerak, benda berwujud atau tidak berwujud sepanjang memiliki nilai ekonomis. Benda 
bergerak seperti pakaian, sembako. Benda tidak bergerak seperti hak atas tanah, rumah atau bangunan. Benda berwujud seperti contoh benda-benda yang telah disebutkan tadi. Benda tak berwujud seperti pulsa talepon atau pulsa listrik;

Bahwa adapun yang menjadi objek si penerima dari perbuatan yang dilarang itu adalah Peserta Kampanye Pemilu. Menurut Pasal 273 Undang-Undang Nomor 7 Tahun 2017, Peserta Kampanye Pemilu terdiri atas anggota masyarakat. Selanjutnya menurut Pasal 1 angka 25 Peraturan Komisi Pemilihan Umum Nomor 23 Tahun 2018, Peserta Kampanye adalah anggota masyarakat atau Warga Negara Indonesia yang memenuhi syarat sebagai Pemilih;

Bahwa selanjutnya perbuatan tardakwa tersebut harus ada kesengajaan dari Terdakwa. Bahwa menurut doktrin 3 (tiga) bentuk/corak kesengajaan, yaitu:

1) Kesengajaan sebagai maksud (opzet als oogmerk)

Menghendaki untuk mewujudkan suatu perbuatan (commisionis), menghendaki untuk tidak berbuat/melalaikan kewajiban (ommisionis) dan atau menghendaki timbulnya akibat dari perbuatan itu. Ada tujuan yang ingin dicapai oleh pelaku. Antara motivasi seseorang melakukan perbuatan, tindakan, dan akibatnya benar-benar terwujud;

2) Kesengajaan sebagai kepastian (opzet bij zekerheisbewustzijn)

Kesadaran seseorang terhadap suatu akibat yang menurut akal orang pada umumnya pasti terjadi karena dilakukannya perbuatan tertentu. Ada dua akibat yang timbul, yaitu dikehendaki oleh pelaku dan tidak dikehendaki oleh pelaku namun pasti terjadi;

3) Kesengajaan sebagai kemungkinan (opzet bij mogelijkheidsbewustzijn) melakukan perbuatan yang diketahuinya bahwa akibat lain yang mungkin dapat timbul yang ia tidak inginkan dari perbuatan, namun bagitu besarnya kehendak untuk mewujudkan perbuatan itu, ia tidak mundur dan siap mengambil risiko untuk melakukan perbuatan itu.

Bahwa berdasarkan fakta hukum, terdakwa adalah calon anggota DPRD Provinsi Kalimantan Selatan, yang pada hari Sabtu tanggal 16 maret 2019 sekira jam 18.00 Wita di rumah milik saudara M ( alm ) terdakwa F melakukan sosialisasi.

Bahwa pada acara tersebut, tim sukses terdakwa telah membagikan kantong plastik yang berlambang logo partai Demokrat atas nama $\mathrm{F}$ beserta nomor urut Calon legislatifnya dan tulisan " FIKR1 UNTUK RAKYAT “, kantong plastik tersebut berisi 1 (satu) bungkus minyak Goreng merk Tawon, 1 (satu) lembar kerudung wama merah 
jambu, 1 (satu) lembar kartu nama Calon legislatif atas nama YK, dimana semua biaya kampanye tersebut ditanggung oleh Terdakwa

Bahwa dalam sosialisasinya sebagaimana diterangkan oleh saksi $\mathrm{H}$ dan saksi saudara $\mathrm{R}$ dan dibenarkan sendiri oleh terdakwa pada saat kampanye tersebut, terdakwa mempekenalkan diri sebagai anggota DPRD Provinsi Kalimantan Selatan dan juga maju kembali sebagai Caleg, kemudian terdakwa mensosialisasikan pentingnya partisipasi Pemilu Tahun 2019 dan jangan sampai golput serta terdakwa memohon doa dan dukungan untuk maju kembali sebagai Anggota DPRD Provinsi Kalimantan Selatan, sebelumnya tim sukses terdakwa yaitu saksi $\mathrm{H}$ melatih peserta mencoblos gambar terdakwa pada saat pemilu tanggal 17 April 2019 yang lalu;

Bahwa pada saat kampanye tersebut biaya dalam penyelenggaraan kampanye tanggal 16 Maret 2019 tersebut adalah sebesar Rp. 1.500.000,- (satu juta lima ratus ribu rupiah) denga rincian Rp. 500.000 (lima ratus ribu rupiah) untuk baiaya konsumsi yang di serahkan dan di kelola oleh tuan rumah dan sisanya untuk mobilitas tim pemenangan, dan juga bahwa keseluruhan biaya tersebut adalah dana pribadi terdakwa sendiri;

Bahwa berdasarkan perimbangan di atas, majelis hakim berpendapat bahwa terdakwa telah dengan sengaja (kesengajaan sebagai maksud (opzet als oogmerk) memberikan materi berupa kantong plastik yang berisi minyak cap tawon dan kerudung dengan maksud untuk mempengaruhi peserta kampanye agar memilih dirinya pada Pemilu tanggal 17 April 2019 yang lalu;

Bahwa dengan demikian unsur ke dua ini juga terpenuhi ada pada diri Terdakwa. Bahwa dengan terpenuhinya semua unsur Pasal 523 Ayat (1) Jo. Pasal 280 Ayat (1) huruf j Undang -Undang RI Nomor 7 Tahun 2017 tentang Pemilihan Umum, Majelis Hakim menyatakan bahwa Dakwaan tersebut telah terbukti secara sah dan meyakinkan;

Bahwa selama pemeriksaan di persidangan Majelis Hakim tidak menemukan adanya alasan pemaaf atau pembenar yang dapat menghapus pertanggung jawaban pidana terdakwa, maka terdakwa harus dinyatakan bersalah dan dijatuhi pidana.

Bahwa dengan terbuktinya dakwaan penuntut umum, maka terhadap alasan terdakwa yang menyatakan bahwa pemberian tersebut sudah dikonsultasikan dengan Bawaslu, menurut Majelis Hakim alasan tersebut harus dikesampingkan;

Bahwa tentang pidana yang dituntutkan kepada terdakwa, majelis hakim berpendapat tuntutan tersebut terlalu berat, karena nilai materi barang yang diberikan kepada peserta kampanye tersebut tidak terlalu besar yaitu hanya senilai kurang lebih Rp. 
25.000,- (dua puluh lima ribu rupiah) dan ternyata tidak mempengaruhi elektibilitas terdakwa, karena terdakwa pada akhirnya tidak terpilih sebagai Anggota DPRD Provinsi Kalimantan Selatan;

Bahwa kegagalan terdakwa tersebut menurut Majelis Hakim adalah merupakan penderitaan tersendiri bagi terdakwa dan keluarganya, sehingga adalah pantas bila terdakwa diterapkan pidana percobaan sebagaimana ditentukan dalam Pasal 14 (a) Kitab Undang-Undang Hukum Pidana;

Bahwa segala sesuatu yang terjadi di depan persidangan sebagaimana tercantum di dalam Berita Acara Sidang adalah bagian yang tak terpisahkan dengan putusan ini dan telah dipertimbangkan secukupnya;

Bahwa untuk menjatuhkan pidana terhadap terdakwa, maka perlu dipertimbangkan terlebih dahulu keadaan yang memberatkan dan yang meringankan terdakwa; Keadaan yang memberatkan:

- Perbuatan terdakwa tidak sesuai dengan asas Pemilu yaitu Langsung, Umum, Bebas, Rahasia, Jujur dan Adil;

- Keadaan yang meringankan:

- Terdakwa bersikap sopan dalam persidangan;

- Terdakwa mengakui dan menyesali perbuatannya;

- Terdakwa mengaku terus terang sehingga memperlancar jalannya persidangan;

- Terdakwa belum pernah dihukum;

- Minyak goreng tersebut adalah permintaan dari peserta kampanye (warga);

Bahwa oleh karena terdakwa djatuhi pidana maka haruslah dibebani pula untuk membayar biaya perkara. Memperhatikan, Pasal 523 Ayat (1) Jo. Pasal 280 Ayat (1) huruf $j$ Undang-Undang RI Nomor 7 Tahun 2017 tentang Pemilihan Umum dan Undang-Undang Nomor 8 Tahun 1981 tentang Hukum Acara Pidana serta peraturan perundang-undangan lain yang bersangkutan. ${ }^{13}$

Menurut penulis terhadap putusan perkara money politik (materi lainnya sebagai imbalan) di atas, yang mana hakim berpendapat bahwa terdakwa telah dengan sengaja (kesengajaan sebagai maksud (opzet als oogmerk) memberikan materi berupa kantong plastik yang berisi minyak cap tawon dan kerudung dengan maksud untuk mempengaruhi peserta kampanye agar memilih dirinya pada Pemilu tanggal 17 April 2019 yang lalu, dengan terpenuhinya semua unsur Pasal 523 Ayat (1) Jo. Pasal 280 Ayat

\footnotetext{
${ }^{13}$ Putusan Nomor 568/Pid.Sus/2019/PN Bjm
} 
(1) hurufj Undang -Undang RI Nomor 7 Tahun 2017 tentang Pemilihan Umum, Majelis Hakim menyatakan bahwa Dakwaan tersebut telah terbukti secara sah dan meyakinkan, artinya bahwa majelis hakim yang memeriksa perkara ini semestinya mengikuti ancaman hukuman yang terdapat di dalam Pasal 523 Ayat (1) Jo. Pasal 280 Ayat (1) huruf j Undang -Undang RI Nomor 7 Tahun 2017 tentang Pemilihan Umum, yakni pidana penjara bukan pidana bersyarat, yang perbuatan tersebut juga telah diakui oleh terdakwa sendiri dalam pemeriksaan persidangan. Selain itu pula untuk menciptakan efek jera kepada pihak-pihak lain terhadap perbuatan-perbuatan yang dapat merusak tatanan demokrasi, dalam ketentuan Pasal di atas sebaiknya tidak hanya dimuat ancaman maksimal, tetapi juga dimuat ancaman minimal pidana penjara, misalnya saja minimal 1 Tahun untuk tipologi perkara yang mengarah kepada perkara money politik. Sehingga dengan adanya ancaman minimal 1 Tahun ini, pidana bersyarat tidak dapat dijatuhkan atau diputuskan mengingat pidana bersyarat hanya dapat dilaksanakan terhadap putusan hakim dibawah 1 Tahun.

\section{Putusan Nomor 20/PID.SUS/2019/PT Bjm}

Bahwa permintaan banding yang diajukan penuntut umum pada tanggal 28 Januari 2019 terhadap Putusan Pengadilan Negeri Banjarbaru Nomor 20 /Pid.Sus/2018/PN.Bjb, tanggal 24 Januari 2019 telah diajukan dalam tenggang waktu dan menurut cara serta syarat-syarat sebagaimana ditentukan menurut Undang-Undang. oleh karena itu permintaan banding tersebut secara formal dapat diterima;

Bahwa di dalam memori bandingnya tersebut tertanggal 28 Januari 2019 yang diajukan dan ditandatangani oleh penuntut umum yaitu keberatan terhadap Putusan Pengadilan Negeri Banjarbaru Nomor 20/Pid Sus/2018/PN.Bjb tanggal 24 januari 2019 dengan alasan sebagai berikut:

1. Bahwa keberatan mengenai sangat ringannya Hukuman Pidana bagi Terdakwa yang tidak mencerminkan Tujuan Hukum. Azaz Keadilan dari Azas Kepastian Hukum Dagi Masyarakat terutama dalam permindahan tindak pidana Pemilihan Umum tahun 2019;

2. Bahwa Pidana yang dijatuhkan terhadap Terdakwa berupa percobaan selama 6 (enam) bulan tersebut sangat jauh dari keadilan bagi masyarakat dak tidak memberikan mamfaat yang berimbang antara manfaat bagi terdakwa dengan batin masyarakat; 
3. Bahwa hukuman pidana tersebut tidak akan memberikan efek yang cukup signifikan dalam menciptakan adanya ketertiban umum (Kantibum) di masyarakat dalam menyelenggarakan Pemilu 2019 yang berintegritas dan akan menciptakan kondisi apriori (antipati) masyarakat dan bahkan menimbulkan pesimisme bagi para Penegak Hukum yang tergabung dalam Sentra Gakkumdu Banjarbaru (Bawaslu, Kepolisian, dan Kejaksaan) karena selama ini banyaknya perkara tindak pidana pemilu namun ujung-ujungnya hanya diputus pidana sangat ringan oleh Pengadilan yaitu hanya pidana Percobaan di Wilayah Hukum Kalimantan Selatan dalam kurun waktu tahun 2017, 2018, dan 2019;

4. Bahwa situasi dan kondisi pesimisme tersebut seharusnya telah mulai diubah oleh Majelis Hakim untuk menggali nilai-nilai keadilan yang berkembang di masyarakat, hukuman pidana percobaan tersebutpun tidak selaras dan tidak sebanding (equality) dengan ancaman pidana tindak pidana yang tertera dalam Pasal 521 Undang-Undang Nomor 7 Tahun 2017 tentang Pemilihan Umum yaitu maksimal 2 (dua) tahun penjara dan dengan adanya pidana percobaan tersebut pun telah mematahkan semangat dalam upaya penegakan hukum tindak pidana pemilu di wilayah Kalimantan Selatan;

5. Bahwa oleh karenanya sudah sepatutnya kondisi dan situasi atmosphare penegakan hukum Tindak Pidana Pemilu tersebut yang layu tersebut, sudah saatnya mulai diubah oleh Yang Mulia Ketua Pengadılan Tinggi Kalimantan Selatan sebagai upaya hukum terakhir dan tidak ada upaya hukum lain setelah permohonan banding kami ini yaitu dengan cara memberikan hukuman pidana yang lebih berkeadilan bagi masyarakat dan lebih sesuai dengan rasa batin masyarakat yong terus diselimuti pesimisme dalam penegakan hukum yaitu dalam perkara ini dengan cara menghapuskan pidana percobaan bagi terdakwa tersebut;

Bahwa setelah majelis Hakim Pengadilan Tinggi mempelajari dengan seksama berkas perkara serta turunan resmi Putusan Pengadilan Negeri Banjarbaru Nomor 20/Pid.Sus/2019/PN.Bjb tanggal 24 Januari 2019 Pengadilan Tinggi sependapat dengan pertimbangan Majelis Hakim Tingkat Pertama yang dalam putusannya menyatakan bahwa Terdakwa telah terbukti secara sah dan meyakinkan bersalah melakukan tindak pidana melanggar Pasal 521 Jo Pasal 280 Ayat (1) huruf h Undang - Undang Republik Indonesia Nomor 7 Tahun 2017 tentang Pemilihan Umum Jo Pasal 55 Ayat (1) ke-1 KUHP, memperhatikan ketentuan Pasal 14a Ayat (1) dan Ayat (4) KUHP, sehingga 
pertimbangan Majelis Hakim Tingkat Pertama tersebut diambil alih dan dijadikan sebagai pertimbangan Pengadilan Tinggi sendiri dalam memutus perkara ini;

Bahwa terhadap Memori Banding Penuntut mengenai pertimbangan Majelis Hakim Tingkat Pertama yang dianggap mengesampingkan tindakan represif, yaitu dengan menyatakan hukuman percobaan sehingga tidak ada efek jera dari penjatuhan hukuman tersebut, menurut Majelis Hakim Tingkat Banding bahwa terdakwa melakukan perbuatan tersebut karena ketidaktahuan terdakwa dan terdakwa telah bertanya kepada $S$, apakah kalender tersebut dapat dibagikan ke murid-murid atau tidak, dan dijawab oleh saksi S, bahwa kalender tersebut dapat dibagikan tapi diluar lingkungan sekolah;

Bahwa dari pertimbangan tersebut di atas ditambah oleh pertimbangan Pengadilan Tingkat Pertama yang telah diambil alih oleh Majelis Hakim Pengadilan Tinggi Banjarmasin, maka memori banding dari penuntut umum haruslah dikesampingkan;

Bahwa tentang kontra memori banding dari terdakwa, setelah Majelis Hakim Tingkat Banding membaca dan meneliti, ternyata tidak ada hal-hal baru, oleh karena itu kontra memori banding dari tardakwa haruslah dikesampingkan;

Bahwa oleh karena Putusan Majelis Hakim Tingkat Pertama sudah tepat dan benar, dan pertimbangan Majelis Hakim Tingkat Pertama tersebut diambil alih dan dijadikan sebagai pertimbangan Pengadilan Tinggi sendiri, maka Putusan Pcngadilan Negeri Banjarbaru Nomor 20/Pid.Sus/2019/PN.Bjb tanggal 24 Januari 2019 harus dipertahankan untuk dikuatkan;

Bahwa oleh karena terdakwa dinyatakan bersalah dan dijatuhi pidana, maka kepada terdakwa dibebani untuk membayar biaya perkara dalam kedua tingkat pengadilan;

Bahwa mengingat dan memperhatikan Pasal 521 Jo Pasal 280 Ayat (1) huruf h Undang - Undang Republik Indonesia Nomor 7 Tahun 2017 tentang Pemilihan Umum Jo Pasal 55 Ayat (1) ke-1 KUHP, ketentuan Pasal 14a Ayat (1) dan Ayat (4) KUHP, serta Undang-Undang Nomor 8 Tahun 1981 tentang KUHAP serta peraturan perundangundangan yang berkaitan dengan perkara ini. ${ }^{14}$

Menurut penulis terhadap putusan pidana pemilu terhadap larangan pelaksanaan kampanye di atas, yang mana hakim Pengadilan Tinggi Banjarmasin berpendapat bahwa terdakwa telah terbukti secara sah dan meyakinkan bersalah melakukan tindak pidana melanggar Pasal 521 Jo Pasal 280 Ayat (1) huruf h Undang -

\footnotetext{
${ }^{14}$ Putusan Nomor 20/PID.SUS/2019/PT Bjm
} 
Undang Republik Indonesia Nomor 7 Tahun 2017 tentang Pemilihan Umum Jo Pasal 55 Ayat (1) ke-1 KUHP, jika memperhatikan ketentuan Pasal 14a Ayat (1) dan Ayat (4) $K U H P$, yakni pidana penjara bukan pidana bersyarat, akan tetapi diputus pidana bersyarat, apalagi perbuatan tersebut juga telah diakui oleh terdakwa sendiri dalam pemeriksaan persidangan. Semestinya jika dikembalikan kepada ketentuan Pasal $14 a$ Ayat (1) dan Ayat (4) KUHP, dengan vonis pidana penjara bertujuan menciptakan efek jera kepada pihak-pihak lainnya kedepan terhadap perbuatan-perbuatan yang dapat merusak tatanan demokrasi, selain itu pula dalam ketentuan Pasal di atas sebaiknya tidak hanya dimuat ancaman maksimal, tetapi juga dimuat ancaman minimal pidana penjara. Sehingga dengan adanya ancaman minimal 1 Tahun ini, pidana bersyarat tidak dapat dijatuhkan atau diputuskan oleh Majelis Hakim mengingat pidana bersyarat hanya dapat dilaksanakan terhadap putusan hakim dibawah 1 Tahun.

\section{Putusan Nomor 102/PID.SUS/2019/PT Bjm}

Bahwa berdasarkan tuntutan dari Jaksa Penuntut Umum pada Kejaksaan Negeri Banjar No. Reg.Perkara PDM 114/Marta/Euh.2/07.2019, (Alm) bersalah melakukan tindak pidana "Penyelenggara Pemilu yang melakukan perbuatan yang menyebabkan şuara seorang Pemilih menjadi tidak bernilai, atau menyebabkan Peserta Pemilu tertentu mendapat tambahan şuara atau perolehan Şuara Peserta Pemilu menjadi berkurang” sebagaimana diatur dan diancam pidana dalam Pasal 532 Jo Pasal 554 UU Nomor 7 Tahun 2017 tentang Pemilu sebagaimana dalam Dakwaan Kesatu Penuntut Umum;

Bahwa setelah Majelis Hakim Tingkat Banding mempelajari dengan seksama berkas perkara dan turunan resmi putusan Pengadilan Negeri Martapura tanggal 25 Juli 2019 Nomor 187/Pid.Sus/2019/PN Mtp, serta memori banding Jaksa Penuntut Umum, Majelis Hakim Tingkat Banding sependapat dengan pertimbangan Hakim Tingkat Pertama dalam putusannya bahwa Terdakwa terbukti secara sah dan meyakinkan bersalah melakukan tindak pidana sebagaimana yang di dakwakan kepadanya dalam dakwaan alternatif kesatu pertimbangan Majelis Hakim tingkat banding sendiri dalam memutus perkara 1nı dalam tingkat banding;

Bahwa namun demikian oleh karena dalam perkara ini terdakwanya 1 (satu), maka redaksi dari amar putusan harus diperbaiki sepanjang mengenai kalimat dalam amar putusan Pengadilan Negeri Martapura tanggal 25 Juli 2019 Nomor 
187/Pid.Sus/2019/PN Mtp, angka 2 "menjatuhkan pidana kepada Para terdakwa oleh karena itu dengan pidana penjara selama 2 (dua) bulan dan denda sejumlah Rp1.000.000,00 (satu juta rupiah) dengan ketentuan apabila denda tersebut tidak dibayar diganti dengan pidana kurungan selama 1 (satu) bulan" diperbaiki menjadi "menjatuhkan pidana kepada terdakwa oleh karena itu dengan pidana penjara selama selama 2 (dua) bulan dan denda sejumlah Rp.1.000.000,00 (satu juta rupiah) dengan ketentuan apabila denda tersebut tidak dibayar diganti dengan pidana kurungan selama 1 (satu) bulan";

Bahwa memori banding yang diajukan jaksa penuntut umum bertanggal 26 Juli 2019 juga menjadi bagian dari pertimbangan Majelis Hakim Tingkat Banding, namun demikian oleh karena hukum pidana tidak hanya bertujuan untuk memberikan pidana atau nestapa kepada Terdakwa, tetapi pula untuk mendidik, membina dan mengadakan pencegahan agar orang tidak melakukan tindak pidana, maka terhadap pidana yang Majelis Hakim Tingkat Pertama terhadap terdakwa, yaitu pidana selama 2 (dua) bulan dan denda sejumlah Rp.1.000.000,00 (satu juta) dengan ketentuan apabila denda tersebut tidak dibayar diganti dengan kurungan selama 1 (satu) bulan dan pidana tersebut tidak perlu dijalani, kecuali jika dikemudian hari ada putusan Hakim yang menentukan lain disebabkan karena terpidana melakukan suatu tindak pidana sebelum masa percobaan selama 6 (enam) bulan berakhir, menurut Majelis Hakim Tingkat Banding telah tepat, rasional dan sesuai rasa keadilan, oleh karena itu memori banding Penuntut Umum tersebut harus dikesampingkan;

Bahwa berdasarkan pertimbangan tersebut di atas, maka putusan Pengadilan Negeri Martapura tanggal 25 Juli 2019 Nomor 187/Pid.Sus/2019/PN Mtp, yang dimintakan banding tersebut dapat dikuatkan dengan perbaikan amar putusan angka 2 sekedar mengenai kata "Para Terdakwa" diperbaiki menjadi "Terdakwa":

Bahwa mengingat Pasal 532 Jo Pasal 554 Undang-Undang RI Nomor 7 tahun 2017 tentang Pemilihan Umum dan Pasal-Pasal lain dari peraturan perundang-undangan yang bersangkutan dengan perkara ini. ${ }^{15}$

Menurut penulis sama dengan analisis putusan di atas, terhadap putusan pidana pemilu yang terjadi di Kabupaten Banjar dengan cara merubah perolehan suara, yang mana hakim Pengadilan Tinggi Banjarmasin berpendapat bahwa terdakwa telah terbukti secara sah dan meyakinkan bersalah melakukan tindak pidana melanggar Pasal $532 \mathrm{Jo}$ Pasal 554 Undang - Undang Republik Indonesia Nomor 7 Tahun 2017 tentang Pemilihan

\footnotetext{
${ }^{15}$ Putusan Nomor 102/PID.SUS/2019/PT Bjm.
} 
Umum, jika memperhatikan ketentuan Pasal 14a Ayat (1) dan Ayat (4) KUHP, yakni pidana penjara bukan pidana bersyarat, akan tetapi diputus pidana bersyarat, apalagi perbuatan tersebut juga telah diakui oleh terdakwa sendiri dalam pemeriksaan persidangan. Semestinya jika dikembalikan kepada ketentuan Pasal 14a Ayat (1) dan Ayat (4) KUHP, dengan vonis pidana penjara bertujuan menciptakan efek jera kepada pihak-pihak lainnya kedepan terhadap perbuatan-perbuatan yang dapat merusak tatanan demokrasi, selain itu pula dalam ketentuan Pasal di atas sebaiknya tidak hanya dimuat ancaman maksimal, tetapi juga dimuat ancaman minimal pidana penjara. Sehingga dengan adanya ancaman minimal 1 Tahun ini, pidana bersyarat tidak dapat dijatuhkan atau diputuskan oleh Majelis Hakim mengingat pidana bersyarat hanya dapat dilaksanakan terhadap putusan hakim dibawah 1 Tahun.

\section{PENUTUP}

Putusan Pidana Pemilu yang terjadi di Kota Banjarmasin, Kota Banjarbaru, serta Kabupaten Banjar, yang kesemuanya adalah pidana bersyarat dalam proses peradilan tindak pidana pemilu itu penulis dapat disimpulkan bahwa masih adanya perbedaan atau disparitas putusan dan banyaknya vonis pidana percobaan (ringan) menunjukkan adanya perbedaan perspektif (paradigma) di kalangan hakim dalam memandang kasus tindak pidana pemilu sebagai berikut

1. Bahwa sebagian besar para hakim menilai bahwa pemidanaan (straafinaad), termasuk pemidanaan kasus pemilu bukan merupakan ajang balas dendam, sehingga dalam pandangan ini vonis yang dijatuhkan lebih merupakan langkah korektif dan pembinaan terhadap pelaku.

2. Bahwa para hakim dapat menilai tindak pidana pemilu dalam perspektif yang lebih dalam bahwa tindak pidana pemilu sudah mencederai rasa keadilan masyarakat dan merusak tatanan penyelenggaraan pemerintahan yang demokratis. Sehingga pembalasan terhadap tindak pidana Pemilu harus lebih diutamakan agar memberikan efek jera (determinasi). Keduanya, memang berada pada wilayah independensi hakim, yang seharusnya dapat ditunjang dengan akuntabilitas yang tercermin dari putusan-putusannya.

Dengan adanya kesalahan penerapan aturan dalam putusan yang masih terjadi dalam perkara tindak pidana pemilu, sekalipun tafsir hakim yang muncul dalam pertimbangan putusan dibenarkan namun kekurangan jelasan regulasi juga menjadi faktor penyebab yang membuat putusan hakim wajib dikoreksi dan bermasalah saat akan dieksekusi. 
Dalam kasus-kasus tindak pidana pemilu di atas, hakim bukan menjadi penyebab kegagalan tidak diadilinya semua pelaku pelanggaran pemilu. Namun hakim tentu saja dapat mengingatkan, bahkan meminta atau memerintahkan penegak hukum lainnya untuk memproses secara hukum seluruh pelaku yang terlibat tindak pidana pemilu. Oleh karena itu proses peradilan tindak pidana pemilu dalam memperkuat transparansi dan akuntabilitas penegakan hukum pemilu yang berkeadilan konstitusi, perlu dilakukan revisi atau perbaikan terhadap hal-hal sebagai berikut:

1. Revisi peraturan pidana pemilu baik secara formil (hukum acara) maupun materiil, terutama kejelasan dan penegasan tentang;

a. Stratifikasi terkait pelanggaran/kejahatan yang dapat menuntun para hakim menjatuhkan vonis yang lebih memenuhi rasa keadilan tidak hanya sanksi hukuman maksimal, diharapkan juga memuat ancaman hukuman pidana penjara paling singkat (minimal) 1 Tahun;

b. Boleh tidaknya vonis bebas atau lepas dari tuntutan dapat diajukan banding dalam kasus pidana pemilu;

c. Kualifikasi pelanggaran pidana pemilu yang dapat membatalkan pencalonan atau penetapan caleg.

2. Penguatan perspektif hakim harus ditunjang dengan peningkatan kapasitas dan mutu teknis hakim dalam memeriksa, mengadili dan memutu perkara tindak pidana pemilu. 


\section{DAFTAR PUSTAKA}

\section{Buku}

Peter Mahmud Marzuki, (2014), Penelitian Hukum, Jakarta : Pranamedia Group.

Soerjono Soekanto, dan Sri Mamudji, (2011), Penelitian Hukum Normatif Suatu Tinjauan Singkat, Cet. 13, Jakarta: Rajawali Pers.

Topo Santoso dan Ida Budhiati, (2019), Pemilu di Indonesia (Kelembagaan, Pelaksaanaan, dan Pengawasan), Jakarta: Sinar Grafika.

\section{Peraturan Perundang-Undangan}

Undang-Undang Republik Indonesia Nomor 7 Tahun 2017 tentang Pemilihan Umum.

Peraturan Badan Pengawas Pemilu Nomor 21 Tahun 2018 tentang Pengawasan Penyelenggaraan Pemilihan Umum.

Peraturan Badan Pengawas Pemilu Nomor 7 Tahun 2018 tentang Penanganan Temuan dan Laporan.

Peraturan Badan Pengawas Pemilihan Umum Republik Indonesia Nomor 31 Tahun 2018 tentang Sentra Penegakan Hukum Terpadu.

Peraturan Komisi Pemilihan Umum Nomor 20 Tahun 2018 Pencalonan Anggota Dewan Perwakilan Rakyat, Dewan Perwakilan Rakyat Daerah Provinsi, Dewan Perwakilan Rakyat Derah Kabupaten/Kota.

Peraturan Komisi Pemilihan Umum Nomor 23 Tahun 2018 tentang Kampanye Pemilihan Umum.

Peraturan Komisi Pemilihan Umum Nomor 4 Tahun 2019 tentang Rekapitulasi Hasil Penghitungan Perolehan Suara Dan Penetapan Hasil Pemilihan Umum.

\section{Putusan}

Putusan Nomor 20/Pid.Sus/2019/PT Bjm

Putusan Nomor 81/Pid. Sus/2019/PT Bjm

Putusan Nomor 102/Pid.Sus/2019/PT Bjm

Putusan Nomor 20/Pid.Sus/2019/PN Bjb

Putusan Nomor 187/Pid. Sus/2019/PN Mtp

Putusan Nomor 568/Pid.Sus/2019/PN Bjm 


\section{Jurnal dan Penelitian Lainnya}

Agus Riwanto, (2020), “Model Pengintegrasian Penegakan Hukum Pilkada Serentak Guna Mewujudkan Keadilan Substantif (Evaluasi Penegakan Hukum Pilkada Serentak 2015-2020", Jurnal Adhyasta Pemilu, Volume 7 Nomor 1.

Dudung Mulyadi, (2019), “Analisis Penerapan Bentuk-Bentuk Tindak Pidana Pemilu”, Jurnal Ilmiah Galuh Yustisi, Volume 7 Nomor 1.

Firmansyah Arifin, (2015), "Penegakan Hukum Pemilu : Tinjauan Atas Putusan Pengadilan Tindak Pidana Pemilu 2014”, Jurnal Hukum Prioris, Volume 4 Nomor 3.

Sapto Handoyo D.P, (2018), "Pelaksanaan Pidana Bersyarat Dalam Sistem Pemidaan Di Indonesia", Pakuan Law Review, Volume IV Nomor 1.

Sudi Prayitno, (2020), “Call For Paper Evaluasi Pemilu Serentak 2019 Bidang Evaluasi Aspek, Problematika Penegakan Hukum Tindak Pidana Pemilu 2019”, Journal $K P U$.

Topo Santoso, (2019), "Tindak Pidana Pemilu Di Indonesia: Tinjauan Beberapa Kasus", Makalah Pidana Pemilu, Fakultas Hukum: Universitas Indonesia. 